\section{Acknowledgements}

We acknowledge the support of the Dental ReD Network attached to the Lancashire and South Cumbria Local Dental Network, Donna Hough, Head of Dental Education and Workforce Dentistry for Health Education England North West, and Stevie Agius, Assistant Professor in Medical Education, Faculty of Medicine \& Health Sciences University of Nottingham

\section{References}

1. Public Health England. Urgent Dental Care. Evidence Review 2019; 2019. Available online at https:// www.england.nhs.uk/wp-content/uploads/2019/07/ commissioning-standard-for-urgent-dental-care.pdf (accessed 15 May 2019)

2. Sanderson S. Medico-legal considerations in providing emergency dental care in practice. Prim Dent J 2017; 6 : 20-25.

3. Smits M, Hanssen S, Huibers L, Giesen P. Telephone triage in general practices: A written case scenario study in the Netherlands. Scand J Prim Health Care 2016; 34: 28-36.

4. Mellor R M, Sheppard J P, Bates E et al. Receptionist $r E C o g n i t i o n$ and $r$ Eferral of Patients with Stroke (RECEPTS): unannounced simulated patient telephone call study in primary care. Br J Gen Pract 2015; 65: e421-e427.

5. Huibers L, Smits M, Renaud V, Giesen P, Wensing M. Safety of telephone triage in out-of-hours care: A systematic review. Scand J Prim Health Care 2011; 29: 198-209.

6. Connechen J, Walter R. Telephone Triage in General Practice. Prim Health Care 2006; 16: 36-40.
7. NHS England. Quick Guide: Best use of unscheduled dental care services. 2015. Available online at https:// www.england.nhs.uk/commissioning/wp-content/ uploads/sites/12/2015/11/quick-guid-unscheduleddental-care.pdf (accessed 15 May 2019).

8. Jones K. Comparison of a predictive algorithm with receptionist triage for priority public dental care. Community Dent Oral 2015; 43: 586-592.

9. Scottish Dental Clinical Effectiveness Programme. Emergency Dental Care. 2007; Available at http://www. sdcep.org.uk/published-guidance/emergency-dentalcare/ (accessed 15 May 2019).

10. Heggie C. Triaging of non-scheduled appointments in general dental practice: a clinical audit. Br Dent J 2019; 226: 203-206.

11. Scottish Dental Clinical Effectiveness Programme. Management of Acute Dental Problems. 2007. Available online at http://www.sdcep.org.uk/wp-content/uploads/2013/03/ EDC+Guidance.pdf (accessed 15 May 2019).

12. Cure $R$, Ireland $R$. How are we training the whole dental team? Vita/ 2008; 6: 23-25. Available online at https:// www.nature.com/vital/journal/v6/n1/full/vital891.html (accessed 15 May 2019).

13. Campaign for Administrative Standards and Professional Education for Receptionists and Practice Managers, (CASPER). 'Massive black hole' in manager education. Vital 2012; 9: 9. Available online at https://www.nature. com/vital/journal/v9/n3/full/vital1514.html (accessed 15 May 2019).

14. Evans D J Smith M P, Grant S M, Crawford M A, Bond J. Out-of-hours emergency dental services - development of one possible local solution. Br Dent J 2001; 191: 550-554

15. Ritchie J, Lewis J, McNaughton Nicholls C, Ormston R. Qualitative research practice: A guide for social science students and researchers. London: Sage, 2014.
16. Joffe H, Yardley L. Content and thematic analysis. In Marks D F, Yardley L (eds) Research methods for clinical and health psychology. pp 56-68 London: Sage, 2004.

17. Braun V, Clarke V. Using thematic analysis in psychology. Qual Res Psychol 2008; 3: 77-101.

18. Myers H L, Myers L B. 'It's difficult being a dentist': stress and health in the general dental practitioner. $\mathrm{Br}$ Dent J 2014; 197: 89-93.

19. Eisner M, Britten N. What do general practice receptionists think and feel about their work? Br J Gen Pract 1999; 49: 103-106.

20. Heidari E, Andiappan M, Banerjee A, Newton J T. The oral health of individuals with dental phobia: a multivariate analysis of the Adult Dental Health Survey, 2009. Br Dent. J 2017; 222: 595-604.

21. Vaona A, Pappas Y, Grewal R S et al. Training interventions for improving telephone consultation skills in clinicians. Cochrane Database Syst Rev 2017; CD010034.

22. Tracy S J. Qualitative quality: Eight "big-tent" criteria for excellent qualitative research. Qual Inq 2010; 16: 837-851.

23. Corbin Dwyer S, Buckle J L. Reflection/commentary on a past article: "The space between: on being an insideroutsider in qualitative research". Int I Qual Methods 2018; 17: 160940691878817

24. Gill P, Baillie J. Interviews and focus groups in qualitative research: an update for the digital age. Br Dent J 2018; 225: 668-672.

25. Litchfield I, Gale N, Burrows M, Greenfield S. The future role of receptionists in primary care. Br J Gen Pract 2017 67: $523-524$

26. Health and Social Care Information Centre. Data on written complaints in the NHS. 2017-18. 2018. Available at https://digital.nhs.uk/data-and-information/ publications/statistical/data-on-written-complaints-inthe-nhs/2017-18 (accessed 15 May 2019).

\title{
Correction to: A randomised controlled trial of a smartphone application for improving oral hygiene
}

The original article can be found online at https://doi.org/10.1038/s41415-019-0202-1

Author's correction note:

\section{Clinical article Br Dent J 2019; 226: 508-511.}

The authors here provide a note to further explain some sections of the paper that may have caused confusion.

\section{Proportional reduction}

A decision was made that as this was a trial to compare the effectiveness of two interventions (oral health advice, with and without the Brushlink device) in promoting plaque control, that proportional reductions in plaque would be the most suitable comparator. Whilst there are issues with proportional, as opposed to absolute plaque reductions, if the clinical significance of the reduction is under test, in a trial which was solely examining plaque control in relation to use of the device, proportional reduction was considered appropriate. The conclusion drawn from the results is that the device improves toothbrushing. Further long term trials are required to examine the device's effect on gingival and periodontal health.

The conclusions drawn are limited to what is shown by the data. Firstly that tooth cleaning is improved when the device is employed and that this finding fits with behavioural theory, and, secondly, that the device (and others like it) offer a fundamentally important research tool to truly examine the relationship between toothbrushing and clinical outcomes.

\section{Data analysis}

Full mouth plaque scores and Brushlink scores of the test and control groups were compared using independent two sample t-tests. Comparisons between baseline scores and scores after two weeks, and comparisons between baseline scores and scores after four weeks were also made, again using Student's t-test.

\section{Sample size calculation}

A sample size of 49 in each group would allow differences in means of 20 to be detected at $90 \%$ power, assuming a common standard deviation of 30, using a 0.050 two-sided significance level.

The two key points derived from the analysis of the paper are that provision of instant feedback, such as the Brushlink device provides, fits with every behavioural change theory, and, most importantly, that devices like this have absolutely massive potential as research tools in both periodontology and oral health promotion.

The authors apologise for any confusion caused. 